\title{
THE REFUGEE CONVENTION IN THE 21ST CENTURY
}

\section{Susan Glazebrook*}

Over the last decade a series of humanitarian crises such as the Syrian conflict has seen an explosion in the number of refugees and internally displaced persons around the world. The resulting unprecedented movement of people has placed a strain on the 1951 Convention relating to the Status of Refugees. This article discusses the operation of the Convention in the 21st century, with a particular focus on the position of women and children. It analyses whether the Convention is adequately protecting the needs of the world's refugees in light of the current crises and other challenges such as climate change. Alternative international initiatives are also discussed.

\section{INTRODUCTION}

The Convention relating to the Status of Refugees ${ }^{1}$ was entered into in the wake of the Second World War. ${ }^{2}$ This article examines the role of the Convention in the 21 st century. ${ }^{3}$ First it draws attention to those at risk of suffering or currently suffering serious harm who are theoretically covered by the Convention but cannot in practical terms take advantage of the protections guaranteed by it. Then it turns to those at risk of serious harm or suffering serious harm who are not covered by the

* Judge of the Supreme Court of New Zealand. Thanks to my clerks, Josie Beverwijk and Nichola Hodge, for their invaluable assistance with this article. It has been updated from the original version given at the symposium in 2017 where it was possible to do so without substantially altering the text.

1 Convention relating to the Status of Refugees 189 UNTS 137 (opened for signature 28 July 1951, entered into force 22 April 1954). Originally the Convention was limited to events that occurred before 1 January 1951 in Europe. A 1967 Protocol abolished these temporal and geographical restrictions: Protocol relating to the Status of Refugees 606 UNTS 267 (opened for signature January 31 1967, entered into force October 4 1967) [Refugee Protocol]. In this article, I refer to the Refugee Convention and the Refugee Protocol collectively as the "Refugee Convention" or the "Convention". As of October 2018 the Convention has been ratified by 145 State Parties and the Refugee Protocol has 146 parties.

2 See James Hathaway The Rights of Refugees under International Law (Cambridge University Press, Cambridge, 2005) for a discussion of the history of international refugee law.

3 The issues with the Convention are discussed in more detail in Susan Glazebrook "Protecting the vulnerable in the 21 st century: an international perspective" (paper based on the Shirley Smith Address, Wellington, 17 September 2014) available at <www.courtsofnz.govt.nz>. 
Convention at all. These include internally displaced persons and (likely) those displaced by climate change or natural disasters. The article then discusses the serious strain placed on the Convention by the current levels of global displacement and examines some of the responses of states and the global community to these issues. Finally, the article attempts to draw some of these themes together.

\section{SOME STATISTICS}

According to United Nations (UN) High Commissioner for Refugees (UNHCR) 68.5 million individuals had been forcibly displaced by the end of 2017. ${ }^{4}$ The total number of people displaced is the highest since the aftermath of the Second World War. ${ }^{5}$ The growth in numbers was particularly concentrated between 2012 and 2015, mainly as a result of the Syrian conflict and other conflicts in that region, ${ }^{6}$ as well as those in sub-Saharan Africa. ${ }^{7}$ By comparison, in 1997 the figure was 33.9 million.

As at 19 April 2018, some 5.6 million Syrians have been registered as refugees, with an estimated 6.6 million internally displaced persons in Syria and a further 2.98 million in besieged or hard to reach areas. ${ }^{8}$ The second largest population of displaced persons was from Columbia (7.9 million), ${ }^{9}$ followed by the Democratic Republic of the Congo with 5.1 million forcibly displaced and Afghanistan with 4.8 million forcibly displaced. ${ }^{10}$ In 2016 the fastest-growing refugee population was from South Sudan. The number of refugees from South Sudan grew 64 per cent in the second half of 2016, from 854,100 to over 1.4 million. ${ }^{11}$ In 2017 the total number of displaced South Sudanese reached 4.4 million. $^{12}$

4 United Nations High Commissioner for Refugees (UNHCR) Global Trends: Forced Displacement in 2017 (2017) at 2 [Global Trends 2017]. This information is current as of 15 May 2018.

5 Estimated to be approximately 60 million people.

6 Including in Iraq and Yemen.

7 Including Burundi, the Central African Republic, the Democratic Republic of the Congo, South Sudan and Sudan.

8 For more, see UNHCR "Syria emergency" (last updated 19 April 2018) <www.unhcr.org>.

9 Mostly within their own country: Global Trends 2017, above n 4, at 6.

10 At 6

11 United Nations High Commissioner for Refugees Global Trends: Forced Displacement in 2016 (2016) [Global Trends 2016] at 2.

12 Global Trends 2017, above n 4, at 6. 
To these must be added the plight of the Rohingya people. ${ }^{13}$ A military offensive after an attack on an army post in October 2016 caused tens of thousands of Rohingya Muslims to flee from their homes in Myanmar to neighbouring Bangladesh. ${ }^{14}$ Similar attacks in August 2017 and the military response have caused over 500,000 more to flee. ${ }^{15}$ Although the rate of refugees fleeing from Myanmar has slowed, the United Nations High Commissioner for Refugees has recognised them as being in critical need of international protection as they are both refugees and stateless. ${ }^{16}$ A recent report has characterised the military actions as including violations that amount to the "gravest crimes under international law". 17

Of the total 68.5 million displaced persons at the end of 2017, 25.4 million were refugees, ${ }^{18}$ 3.1 million were asylum seekers and the remaining 40 million were internally displaced persons. ${ }^{19}$ Children under 18 made up around half of the refugee population in 2017, as has been the trend in

13 The majority of Rohingya are Muslim, but some are Hindu. They are nevertheless, commonly referred to as the Rohingya Muslims.

14 UNHCR 2016 Report on Mixed Movements in South-East Asia (April 2017) at 3.

15 UNHCR Mission report of OHCHR rapid response mission to Cox's Bazar, Bangladesh (October 2017) at 2. An estimated 130,000 are internally displaced in camps in the northern state of Rakhine in Myanmar: "Myanmar's military must be prosecuted for Rohingya 'ethnic cleansing', UN told" The Guardian (online ed, London, 28 August 2018); and Vivien Maidaborn "The other side of Myanmar's Rohingya crisis" (12 November 2018) Stuff <www.stuff.co.nz>. Another 925,000 are estimated to be in refugee camps in Bangladesh: Chris Melzer "Rohingya returns only 'at their freely expressed wish' - UN refugee chief" (12 November 2018) UN News <news.un.org>.

16 Global Trends 2017, above n 4, at 24-25. The Rohingya people are considered stateless as they are not recognised as citizens in Myanmar. There is also concern about involuntary deportation of Rohingya refugees from Bangladesh back to Myanmar, as the UNHRC considers the situation still unsafe: Shaikh Azizur Rahman and Hannah Ellis-Petersen "Rohingya fears grow as refugees face forcible return to Myanmar" The Guardian (online ed, London, 11 November 2018).

17 Report of the detailed findings of the Independent International Fact-Finding Mission on Myanmar (UN Human Rights Council, September 2018). See also Hannah Ellis-Petersen "Myanmar's military accused of genocide in damning UN report" The Guardian (online ed, London, 27 August 2018); and Michael Safi "'Tied to trees and raped': UN report details Rohingya horrors" The Guardian (online ed, London, 18 September 2018).

18 Of these, 19.9 million refugees were under the UNHCR mandate and 5.4 million were under that of the United Nations Relief and Works Agency for Palestine Refugees in the Near East: Global Trends 2017, above n 4, at 4. For more information on the UNHCR's mandate see: UNHCR "Note on the mandate of the High Commissioner Refugees and His Office" (October 2013) <www.unhcr.org>.

19 The 10 largest internally displaced persons populations (in order of magnitude) were in Columbia, Syria, Democratic Republic of the Congo, Iraq, Somalia, Yemen, Sudan, South Sudan, Afghanistan and Ukraine: Global Trends 2017, above n 4, at 33-35. 
recent years. ${ }^{20}$ During 2017 there were 16.2 million people newly displaced by conflict or persecution, including 11.8 million internally displaced and 4.4 million new refugees and asylum seekers. ${ }^{21}$ Further, by the end of 2017 some two thirds of refugees (13.4 million) were in protracted refugee situations, ${ }^{22}$ and some 3 million of these had been in that situation for 38 years or more. ${ }^{23}$

\section{UNABLE TO ACCESS PROTECTIONS}

\section{A Women and Girls}

Women and children are likely to be disproportionately represented in those who, despite meeting the requirements of the Convention, cannot take advantage of its protections or are imperfectly protected by it. I first take the example of those who have been subjected to domestic violence. The World Health Organization estimates that over one third of women worldwide have experienced either physical or sexual domestic violence or non-domestic sexual violence. ${ }^{24}$ Most is intimate partner violence, which accounts for some 38 per cent of all murders committed worldwide. ${ }^{25}$

To claim refugee status under the Refugee Convention, there must be a well-founded fear of being "persecuted". ${ }^{26}$ The concept of persecution has two key constituents: "the severe violation of human

20 Children make up some 31 per cent of the total world population. Some 75,000 unaccompanied or separated children under the age of 18 claimed asylum in 70 countries in 2016: Global Trends 2016, above n 11, at 7. In 2017 provisional data indicated that the number of unaccompanied or separated children under the age of 18 claiming asylum had dropped to 45,500, with 67 countries reporting at least one application. This figure is believed to be an underestimate as the result of underreporting: Global Trends 2017, above n 4, at 48-49.

21 This equated to 31 people every minute or 44,400 people every day being forced to flee their homes: Global Trends 2017, above $\mathrm{n}$, at 2 .

22 Defined as being where 25,000 or more refugees of the same nationality have been in exile in a particular country for five consecutive years: at 22 .

23 Mainly Palestinian refugees in Egypt and Afghans in Pakistan and Iran: at 22-23. These figures were similar in 2009: see Gil Loescher and James Milner "Understanding the challenge" (2009) 33 Forced Migration Review 9.

24 World Health Organization "Violence against women" (29 November 2017) <www.who.int>. See also Family Violence Death Review Committee (New Zealand) Fifth Report Data: January 2009 to December 2015 (Health Quality and Safety Commission, 20 June 2017); Tracy Cussen and Willow Bryant Domestic/family homicide in Australia (Australian Institute of Criminology, No 38, May 2015); Office for National Statistics Domestic abuse in England and Wales: year ending March 2016 (December 2016); Violence Policy Center When Men Murder Women: An Analysis of 2015 Homicide Data (September 2017); Mohammad Abu Taher and Siti Zaharah Binti Jamaluddin "Bangladesh's Legislative Response Towards Dowry and Dowry-Related Violence Against Women" (2014) Lawasia Journal 99; Melissa L Breger "Transforming Cultural Norms of Sexual Violence against Women" (2014) 4 Journal of Research in Gender Studies 39; and J Cohan "Honor Killings and the Cultural Defense" (2010) 40 Cal W Intl LJ 177.

25 World Health Organization, above n 24.

26 Refugee Convention, above n 1, art 1(A)(2). 
rights accompanied by a failure of the state to protect the individual". ${ }^{27}$ Or, as Lord Hoffmann succinctly put it, "Persecution = Serious Harm + The Failure of State Protection". ${ }^{28}$

The serious harm or the failure of state protection must also be linked to a Convention ground. ${ }^{29}$ The Refugee Convention deals with persecution based on five grounds: race, religion, nationality, being a member of a particular social group and political opinion. Gender is not specifically mentioned and the UNHCR has recognised that the refugee definition has historically "been interpreted through a framework of male experiences". ${ }^{30}$ The modern approach worldwide, however, is to recognise women as a particular social group for the purpose of the Convention. ${ }^{31}$

This has meant an increasing willingness to allow women to claim refugee status in cases where their home state has failed to protect them adequately from violence at the hands of private actors. ${ }^{32}$ This applies in particular to those at risk of being subjected to extreme violence such as female genital mutilation. ${ }^{33}$

The reality is, however, that most victims of domestic violence are unable to seek the protection of the Convention, even if they come within it. In order to claim the protections of the Convention a claimant must first reach the territory of a state party to the Convention. ${ }^{34}$ Many women cannot do so

27 Andreas Zimmermann and Claudia Mahler "Article 1A, para 21951 Convention" in Andreas Zimmermann (ed) The 1951 Convention Relating to the Status of Refugees and its 1967 Protocol: A Commentary (Oxford University Press, New York, 2011) 281 at 345.

28 Islam v Secretary of State for the Home Department [1999] 2 AC 629 (HL) at 653.

29 This applies either to the "serious harm" or the "failure of state protection" element of persecution.

30 UNHCR Guidelines on International Protection: Gender-Related Persecution within the context of Article 1A(2) of the 1951 Convention and/or its 1967 Protocol relating to the Status of Refugees (HCR/GIP/02/01, 7 May 2002) [UNHCR Guidelines on Gender-Related Persecution] at [5].

31 See for example Islam, above n 28; Fornah v Secretary of State for the Home Department [2006] UKHL 46, [2007] 1 AC 412; and Minister for Immigration and Multicultural Affairs v Khawar [2002] HCA 14, (2002) 210 CLR 1. See also UNHCR Guidelines on Gender-Related Persecution, above n 30, at [28]-[31].

32 See for example Minister for Immigration and Multicultural Affairs v Khawar, above n 31; Islam, above $\mathrm{n}$ 28; and Matter of A-R-C-G 26 I\&N Dec 388 (BIA 2014). In New Zealand, see Refugee Appeal No 71427/99 [2000] NZAR 545 (RSAA); Refugee Appeal No 76044 [2008] NZAR 719 (RSAA); and Re BR (Fiji) [2012] NZIPT 800019. However, contrast Re BJ (Sri Lanka) [2014] NZIPT 800512.

33 See for example Fornah v Secretary of State for the Home Department, above n 31; E v Refugee Appeals Tribunal [2009] IEHC 5 (HC); and 27 CE, Ass, 21 December 2012, Mlle E, Mme F, et OFPRA c/Mme B confirmed by CE 9e et 10e sous sections réunies, 30 December 2014, N³67428. For more, see UNHCR Guidance Note on Refugee Claims Relating to Female Genital Mutilation (May 2009); and Annemarie Middelburg and Alina Balta "Female Genital Mutilation/Cutting as a Ground for Asylum in Europe" (2016) 28 IJRL 416.

34 That is not to say that a person has to arrive in a Contracting State to be a refugee or that status as a refugee requires a determination by a Contracting State. A person is a refugee as soon as they fulfil the Convention 
and indeed may be unable to leave their own countries at all. ${ }^{35}$ In many cases women cannot even leave the perpetrator. Often this inability to leave is due to lack of economic resources. Women in most countries earn on average only 60 to 75 per cent of men's earnings. ${ }^{36}$ Women's mobility may be further curtailed because many have the primary child rearing role. ${ }^{37}$ There are also the dangers of flight. It has often been said that the most dangerous time for women in relation to domestic violence can be when they attempt to leave a relationship. ${ }^{38}$

\section{B Refugee Camps}

The existence of refugee camps is another example of the Convention not adequately protecting refugees. The New York Declaration for Refugees and Migrants of 19 September 2016 (New York Declaration) recognises that refugee camps should be the exception and only temporary. ${ }^{39}$ It says that a minority of refugees are in camps but, ${ }^{40}$ given the size of the minority, it can hardly be said that refugee camps are the exception.

In 2017 nearly 5 million people were in refugee camps. ${ }^{41}$ In 2015 the largest refugee camp was Kakuma in Kenya, housing occupants primarily from South Sudan and Somalia. ${ }^{42}$ The population of

criteria: UNHCR Handbook on Procedures and Criteria for Determining Refugee Status (1979) at [28]. However, the obligations of a state, party to the Convention, owed to a refugee can necessarily only occur when a refugee is at minimum within that state's jurisdiction. For more, see Hathaway, above n 2, at ch 3.

35 The Convention would not apply in this case as it requires that those seeking its protection need to have left their home jurisdiction: see Glazebrook, above n 3, at 13-14.

36 See the World Bank "Key Gender-Relevant Employment Indicators from Middle and High Income Countries" (2016) <www.datatopics.worldbank.org>. See also World Economic Forum The Global Gender Gap Report 2017 (2017); and Quentin Wodon and Benedicte De La Briere The Cost of Gender Inequality: Unrealized Potential: The High Cost of Gender Inequality in Earnings (30 May 2018).

37 Kathleen Newland Seeking Protection: Women in Asylum and Refugee Resettlement Processes (United Nations Division for the Advancement of Woman, CM/MMW/2003/EP.8, 14 January 2004) at 5.

38 Lyn Shipway Domestic Violence: A Handbook for Health Professionals (Routledge, London, 2004) at 26. This is in addition to the other dangers of flight discussed below.

39 New York Declaration for Refugees and Migrants GA Res 71/1 (2016) at [73].

40 At [73]. Some 61 per cent of refugees around the world lived in individual private accommodation at the end of 2017, a decrease from recent years: Global Trends 2017, above n 4, at 60 .

41 4,977,200 refugees were in planned/managed camps. Another 1,084,900 were in self-settled camps and 131,100 were in reception/transit camps: Global Trends 2017, above n 4, at 60.

42 In light of the influx of Rohingya refugees it is likely that Bangladesh refugee camps will now have some of the largest populations. Bangladesh has recently announced plans to build a new refugee camp next to the existing Kutupalong camp of 1,000 acres. This is in addition to the 2,000 acres set aside for the Rohingya refugees in September 2017: Agence France Presse "Bangladesh to build one of world's largest refugee camps for 800,000 Rohingya" The Guardian (online ed, London, 6 October 2017). 
that camp was $184,550 .{ }^{43}$ The next three largest camps were also in Kenya, housing in total 277,310 people. ${ }^{44}$ Then comes the Zaatari camp in Jordan housing 77,781 people in $2015,{ }^{45}$ followed by Yida in South Sudan, housing 70,331, ${ }^{46}$ Katumba in Tanzania, housing $66,416,{ }^{47}$ Pugnido in Ethiopia, housing 63,262, ${ }^{48}$ Panian in Pakistan, housing 62,264, ${ }^{49}$ and Mishano in Tanzania, housing 62,264. 50

While refugee camps may offer protection from the original persecutors, the conditions and struggles faced in refugee camps are sometimes arguably almost as harrowing as the events that forced the refugees there. There are often problems with basic sustenance, access to clean water, security and sanitation. ${ }^{51}$ In addition to sustenance and health issues, refugees can face threats from other refugees and from locals. 52

Women and girls also disproportionately face the particular threat of rape and sexual abuse in refugee camps and outside these facilities. ${ }^{53}$ This can take the form of sexual extortion for basic necessities and personal documentation, including for recognition as a refugee. ${ }^{54}$ The issues are

43 Kakuma was established in 1992. These figures and the following were taken from UNHCR Life in Limbo: Inside the World's 10 Largest Refugee Camps (2016).

44 Being Hagdera $(105,998)$, Daghaley $(87,223)$ and Ifo $(84,089)$. These camps were all established in 1992 and the occupants are primarily from Somalia.

45 Established in 2012 with occupants primarily from Syria.

46 Established in 2012 with occupants primarily from Sudan.

47 Established in 1972 with occupants primarily from Burundi.

48 Established in 1993 with occupants primarily from South Sudan.

49 Established in 2008 with occupants primarily from Afghanistan.

50 Established in 2014 with occupants primarily from Burundi.

51 For more see Inside the World's 10 Largest Refugee Camps, above n 43.

52 For example, in Kenyan refugee camps there was often ethnic and tribal fighting: Stephen Legomsky "Secondary Refugee Movements and the Return of Asylum Seekers to Third Countries: The Meaning of Effective Protection" (2003) 15 IJRL 567 at 595. On the island of Nauru, there have been tensions between the locals and the more than 400 asylums seekers detained there: Michael Edwards "Tensions on Nauru heightened after serious of attacks on refugees by locals" (20 March 2015) ABC Austral ia <www.abc.net.au>.

53 UNHCR "Refugee Women" (2014) <www.unhcr.ca>; UNHCR Sexual and Gender Violence against Refugees, Returnees and Internally Displaced Persons: Guidelines on Prevention and Response (2003); and Radhika Coomaraswamy Report of the Special Rapporteur on Violence Against Women, its causes and consequences UN Doc E/CN 4/1998/54 (26 January 1998) at [280]. For a recent report, see Dubravka Šimonović Report of the Special Rapporteur on violence against women, its causes and consequences UN Doc A/HRC/35/30 (2017).

54 Extorting sexual favours by a person in a position of authority, whether government officials, judges, educators, law enforcement personnel, or employers, in exchange for something within their power to grant or withhold has been termed "sextortion" by the International Association of Women Judges (IAWJ): IAWJ 
compounded by the fact that this abuse is often not reported, given the cultural stigma placed on victims of sexual violence and sexual extortion. ${ }^{55}$ Women and girls in refugee camps are also at risk of trafficking. For example, trafficking of Nigerian women who arrive in Italy from Libya has been described as being at "crisis levels" with "traffickers using migrant reception centres as holding pens for women who are then collected and forced into prostitution across Europe". 56

The first method of leaving a camp is voluntary repatriation which, for obvious reasons, is the UNHCR's most desired outcome. ${ }^{57}$ The problem is that the causes of people becoming refugees are often not transient issues, meaning that realistically individuals are unable to return home. Returnees have represented less than five per cent of the overall refugee population since 2013, well below the number of new arrivals in refugee camps each year. ${ }^{58}$ The situation for many of these returnees remains difficult, given that many return to fragile and unstable environments.

The second means of leaving a camp is local integration into the countries where refugee camps are situated. However, most of those countries are not in a position to accommodate refugees as many are in poverty themselves. ${ }^{59}$ In 2017 developing regions hosted 85 per cent of the refugees under the UNHCR's mandate, with the "Least Developed Countries"60 providing asylum to 28 per cent of

Combating Sextortion: Comparative Study of Laws to Prosecute Corruption Involving Sexual Exploitation (2015). For more see Nancy Hendry "Sextortion and a Gendered Approach to Corruption: Grassroots Women and Women Judges Take the Lead" (speech given at the NGO Committee on the Status of Women Forum Parallel Event, New York, 6 March 2013).

55 See Mark Townsend "Women and children 'endure rape, beatings and abuse' inside Dunkirk's refugee camp" The Guardian (online ed, London, 12 February 2017). See also LaShawn Jefferson and others (eds) Seeking Protection: Addressing Sexual Violence in Tanzania's refugee camps (Human Rights Watch, October 2000) at $89-90$.

56 Annie Kelly and Lorenzo Tondo "Trafficking of Nigerian women into prostitution in Europe 'at crisis level'" The Guardian (online ed, London, 8 August 2016).

57 Global Trends 2016, above n 11, at 25-26.

58 At 25-26. The number of refugees returning to their country in 2016 however was more than double that of 2015 and the highest since 2008: at 25. This further increased in 2017 with the number of refugees returning to their countries of origin climbing from 552,200 in 2016 to 667,400 in 2017: Global Trends 2017, above n 4 , at 28 .

59 As recognised by Stephen Legomsky "Secondary Refugee Movements and the Return of Asylum Seekers to Third Countries: The Meaning of Effective Protection" (2003) 15 IJRL 567 at 595. See also Bart de Bruijn The Living Conditions and Well-being of Refugees (United Nations Development Programme, Human Development Research Paper 2009/25, July 2009) at 18.

60 As defined by the United Nations Economic Analysis and Policy Division "Least Developed Countries (LDCS)" United Nations <www.un.org>. 
refugees (4.9 million). ${ }^{61}$ Lebanon hosted the largest number of refugees in relation to its national population (one in six people were a refugee) followed by Jordan (one in 14) and Turkey (one in 23). ${ }^{62}$

The third means of leaving a camp is through the UNHCR resettlement programme, which is administered under agreements with states to accept and resettle refugees in their jurisdiction. These agreements may be ad hoc in response to special appeals by the UNCHR, ${ }^{63}$ or they may involve a state's continued commitment to resettle refugees by having a resettlement programme. In 2016, 37 resettlement states admitted 189,300 refugees for resettlement. This number was higher than in $2015,{ }^{64}$ but it decreased in 2017 to 102,800 . It is clear that the chances of resettlement through the UNHCR are slim. ${ }^{65}$

The final method of leaving a refugee camp is seeking asylum by entering a state party's jurisdiction and claiming refugee status. The need (in practical terms) to reach the territory of a Contracting State (and the fact that the Convention does not cover internally displaced persons) can be seen as a design fault. ${ }^{66}$ It is often very expensive to travel to a foreign jurisdiction to seek asylum and only the most mobile can undertake the journey. In addition to the monetary and mobility restrictions on seeking asylum, there are barriers (physical and legal) for asylum seekers and, in many cases, dangers.

Air travel is often precluded through measures taken by states to control entry. A classic example of these "relatively invisible non entrée policies" 67 is imposing "a visa requirement on the nations of genuine refugee-producing countries, enforced by sanctions against any carrier that agrees to transport

61 Global Trends 2017, above n 4, at 20. For information on the UNHCR's mandate see above n 18.

62 Global Trends 2017, above n 4, at 2.

63 For example, in 2013 the UNHCR called on countries to admit 30,000 Syrian refugees for resettlement or humanitarian admission by the end of 2014 , with a focus on protecting the most vulnerable refugees: UNHCR Global Trends 2013 (June 2014) at 19.

64 This is a 77 per cent increase on the 107,100 resettlement figure in the 2015 report. And the number of states offering resettlement programmes has increased from 33 in 2015 to 37 in 2016: Global Trends 2016, above $\mathrm{n} 11$, at 27 . The 2016 report notes that other avenues, such as family reunification programmes and labour mobility schemes, have also provided some measure of protection: at 29.

65 Global Trends 2017, above n 4, at 3. 2017 saw a 54 per cent drop in the number of refugees the UNHCR submitted to states for resettlement due to a decline in resettlement quotas. The UNHCR notes that this drop leaves a "94 per cent gap between needs and actual resettlement places for the year": at 29-30.

66 This requirement has been said to create perverse incentives for states to prevent the initial entry into their territory of potential asylum seekers in order to avoid any legal obligations to refugees arising: Eric A Ormsby "The Refugee Crisis as Civil Liberties Crisis" (2017) 117 Colum L Rev 1191 at 1192.

67 Hathaway, above n 2, at 291. Hathaway says, "Non entrée is a term coined to describe the array of legalized policies adopted by states to stymie access by refugees to their territories": at 291, n 70. 
a person without a visa". ${ }^{68}$ These policies have the result of inhibiting those seeking asylum entering a foreign jurisdiction: only those with forged documentation or those who can successfully lie about their intentions have a chance of reaching such jurisdictions by legitimate means of travel. ${ }^{69}$

Such measures are often not primarily directed at refugees but at controlling unlawful entry of migrants ${ }^{70}$ and of undesirable individuals, including criminals. ${ }^{71}$ Other legitimate concerns can be called in aid of protectionist and exclusionary policies, including international obligations with regard to terrorism, people smuggling and trafficking. ${ }^{72}$

This leaves more dangerous means of travel, including by sea through people smugglers. ${ }^{73}$ It has been estimated that 80 per cent of crossings from Africa to Europe were facilitated by such smugglers. ${ }^{74}$ The International Organisation for Migration reports that, in the first half of 2017, an estimated 101,266 migrants and refugees entered Europe by sea. There were 2,297 recorded deaths or missing persons in that same period. ${ }^{75}$ In 2015 some 500 children died in sea crossings. ${ }^{76}$ Although

68 At 291. See also Tilman Rodenhäuser "Another Brick in the Wall: Carrier Sanctions and the Privatization of Immigration Control" (2014) 26 IJRL 223.

69 Hathaway, above n 2, at 292.

70 Many so called economic migrants are in fact fleeing from intolerable conditions. For more, see Lizzie Dearden "How economic migrants become refugees as they seek a new life" The Independent (online ed, London, 22 November 2016). See also Anthee Carassava and Athens Catherine Philp "EU threat to cut aid for states that won't take back migrants" The Times (online ed, London, 26 August 2017).

71 Subject to other international obligations such as the Refugee Convention, states have a right to control their borders: James AR Nafziger "The General Admission of Aliens Under International Law" (1983) 77 AJIL 804 at 804 . He notes, however, at 807 , the proposition that a state has the power to "exclude all aliens" is in fact of relatively recent origin and many writers cite no authority, regarding the propositions as a self-evident maxim. See for example Kleindienst $v$ Mandel 408 US 753 (1972) at 765; and $R v$ Governor of Pentonville Prison, ex parte Azam [1973] 2 All ER 741 (CA) at 747.

72 For more, see Elizabeth Leiserson "Securing the Borders Against Syrian Refugees: When Non-Admission Means Return" (2017) 42 Yale J Intl L 185 at 187.

73 There are also risks on the transit route taken through the Sahara Desert: see for example UNHCR "New comment: UNHCR shocked at deaths in Sahara Desert" (2 June 2017) <www.unhcr.org>.

74 Tuesday Reitano, Laura Adal and Mark Shaw Smuggled Futures: The Dangerous Path of the Migrant from Africa to Europe (The Global Initiative against Transnational Organized Crime, May 2014) at 1.

75 International Organization for Migration "Mediterranean Update" (5 July 2017) <www.iom.int>.

76 UNHCR Situation of migrants in transit UN Doc A/HRC/31/35 (2016) at [3]. 
migration numbers have started to decline,${ }^{77}$ the ratio of fatalities during the crossings has increased. ${ }^{78}$ Further, there is a risk of refugees becoming trafficking victims. Criminal gangs are reported to be taking advantage of Europe's migration crises and in particular unaccompanied children. ${ }^{79}$

In addition, even where a person does manage to reach a state that is party to the Convention without being trafficked and is granted refugee status, they may have difficulty adjusting to the country of refuge, especially with the background of trauma and persecution that many of them have suffered. ${ }^{80}$

\section{THOSE NOT COVERED BY THE CONVENTION}

There are also many who are at risk of, or currently suffering, serious harm who do not come within the Refugee Convention at all. ${ }^{81}$ Internally displaced persons are not covered by the Convention. ${ }^{82}$ Most commentators consider that the Convention does not include victims of climate

77 This has been attributed to extra measures in preventing sea crossing and reduced search and rescue responses: "Major increase in Europe's refugee and migrant death rate: UNHCR" (4 September 2018) UN News $<$ news.un.org >.

78 For example, deaths by arrival by sea from January to July 2017 were 2.3 per cent, which had nearly doubled from 1.4 per cent in the same period in 2016. The trend has continued into 2018 where, although there have been fewer reported arrivals, the ratio of fatalities to survivors has been higher than previous years, rising from one in 60 to one in 14. See Bel Trew and others "Migrant crossings 'are most treacherous ever"' The Times (online ed, London, 28 April 2018). In 2018 for the period from January to July, one in 18 people died or went missing crossing the Mediterranean, compared to one in every 42 people from the same period in 2017: see "Migrant crisis: Mediterranean crossings deadlier than ever - UNHCR" (3 September 2018) BBC <www.bbc.com>.

79 Jennifer Rankin "Human traffickers 'using migration crisis' to force more people into slavery" The Guardian (online ed, London, 19 May 2016). Women are also at risk: see Annie Kelly and Lorenzo Tondo, above n 56. For more on protracted refugee situations, see Global Trends 2016, above n 11, at 22-23; Jeff Crist "Protracted Refugee Situations" (October 2010) UNHCR <www.unhcr.org>; and Independent Anti-Slavery Commissioner Combating modern slavery experienced by Vietnamese nationals en route to, and within, the UK (September 2017).

80 For a discussion of these issues, see for example R Schweitzer and others "Trauma, Post-Migration Living Difficulties, and Social Support as Predictors of Psychological Adjustment in Resettled Sudanese Refugees" (2006) 40 Aust NZ J Psychiatry 179.

81 I do not suggest by this that the Convention should necessarily be extended to all of the excluded groups, even if it was feasible for this to occur.

82 Internally displaced persons are defined in the UNHCR Guiding Principles on Internal Displacement UN Doc E/CN.4/1998/53/Add.2 reprinted as OCHA/IDP/2004/01 (11 February 1998) at [2] as "persons or groups of persons who have been forced or obliged to flee or to leave their homes or places of habitual residence, in particular as a result of or in order to avoid the effects of armed conflict, situations of generalized violence, violations of human rights or natural or human-made disasters, and who have not crossed an internationally recognized State border". 
change ${ }^{83}$ or natural disasters, even those disasters arguably caused or contributed to by climate change ${ }^{84}$ Some of those displaced by warfare may also not strictly come within the Convention. ${ }^{85}$ Nor does the Convention cover those who seek to migrate for economic reasons regardless of the conditions they are fleeing, unless those conditions include persecution on a Convention ground. ${ }^{86}$

There are international instruments relevant to some of these groups, both general and specific. For example, there are the UN Guiding Principles on Internal Displacement, which restate the human rights and humanitarian law relevant to internally displaced persons. However, while these principles are theoretically helpful, they are, in many respects, aspirational as they presuppose financial resources and a state's administrative ability to deal with the issue and they are not legally binding. Given that mass internal displacements are often in less developed countries, and in crisis situations, international humanitarian assistance and intervention is frequently required. ${ }^{87}$

There have been steps to create a more generalised framework for international natural disaster response, which has tended to be ad hoc to date. ${ }^{88}$ The International Law Commission turned its

83 The predominance of opinion is that victims of climate change are not presently covered by the Refugee Convention unless they are able to demonstrate they are being persecuted separately on another Convention ground. For more, see Jane McAdam Climate Change, Forced Migration and International Law (Oxford University Press, Oxford, 2012) at 44. Views differ on whether the Convention should cover victims of climate change. See for example Tiffany Duong "When Islands Drown: The Plight of 'Climate Change Refugees' and Recourse to International Human Rights Law" (2010) 31 U Pa J Intl L 1239 at 1261-1265; and compare Matthew CM Hill "Closing the Gap: Towards Rights-Based Protection for Climate-Induced Displacement in Low Lying Small Island States" (2016) 20 NZ J Envtl L 43; and Jane McAdam "Seven reasons the UN Refugee Convention should not include 'climate refugees'" Sydney Morning Herald (online ed, Sydney, 6 June 2017).

84 See Robert Glasser "Climate Change is Key Driver of Disasters" (9 August 2017) United Nations Office for Disaster Risk Reduction <www.unisdr.org>; and United Nations Office for Disaster Risk Reduction "Tenyear review finds $87 \%$ of disasters climate-related" (6 March 2015) <www.unisdr.org>.

85 For more, see Penelope Mathew "First Do No Harm: Refugee Law as a Response to Armed Conflict" in David W Lovell and Igor Primoratz (eds) Protecting Civilians During Violent Conflict: Theoretical and Practical Issues for the 21st Century (Routledge, United Kingdom, 2016) ch 10.

86 For the position of migrants generally see above at $\mathrm{n} 70$.

87 UNHCR Guiding Principles on Internal Displacement UN Doc E/CN 4/1998/53/Add 2 (1998, 2nd ed with annotations released in 2011). See also Brookings-Bern Project on Internal Displacement Protecting Internally Displaced Persons: A Manual for Law and Policymakers (The Brookings Institution, October 2008).

88 Organisations attempting to create such a framework include for example the United Nations Office for the Coordination of Humanitarian Affairs and private entities such as Oxfam, Red Cross, Red Crescent, Save the Children, Doctors without Borders, Care, and World Vision. 
attention to the topic in $2007 .{ }^{89}$ Its draft articles reiterate that those affected by disaster are entitled to the protection of human rights law and have a right to be treated in accordance with humanitarian principles. They also set out the parameters of international assistance, affirming such things as a duty to cooperate, a duty of an affected state to seek assistance and the right of other states to offer assistance. $^{90}$

The UN Office for Disaster Risk Reduction has also released the Sendai Framework for Disaster Risk Reduction 2015-2030, which has been endorsed by the UN General Assembly. ${ }^{91}$ The Framework recognises that states have the primary role to play in disaster risk but that the responsibility should be shared with other parties such as business and professional organisations to integrate disaster risk management into business models and the media, which should take an active role in raising public awareness of disaster risk and disaster information. ${ }^{92}$

The most recent UN climate change agreement is the Paris Agreement, which was adopted on 12 December 2015 and entered into force on 4 November $2016 . .^{93}$ There is a clear focus on alleviating the consequences of climate change and associated disasters. For example, the Agreement establishes a global goal of enhancing adaptive capacity to existing climate change ${ }^{94}$ and strengthens and enhances the Warsaw International Mechanism for Loss and Damage associated with Climate Change Impacts (WIM). The latter will involve developing approaches to help vulnerable countries cope with the adverse effects of climate change. ${ }^{95}$ Developed countries must also provide financial support to

89 Report of the International Law Commission on the work of its fifty-ninth session GA Res 62/6 (2007) at [7]. The draft articles and commentaries were adopted on the second reading at the 68th session in 2016 and submitted to the General Assembly recommending the elaboration of a convention: Protection of persons in the event of disasters UN Doc A/71/10 (2016). The draft articles were included in the agenda of the 73rd session of the General Assembly in September 2018: UN Doc A/RES/71/141, A/73/251 (item no 90). See also the International Disaster Response Laws, Rules and Principles that were unanimously adopted by the State Parties to the Geneva Conventions and the International Red Cross Red Crescent Movement on 30 November 2007. See further International Federation of Red Cross and Red Crescent Societies "IDRL Guidelines" <www.ifrc.org>.

90 See generally Report of the International Law Commission: Sixty-eighth session UN Doc A/71/10 (2016); and Report of the International Law Commission on the work of its sixty-eighth session (2016) UN Doc A/CN.4/703 (22 February 2017) at 25-28.

91 Sendai Framework for Disaster Risk Reduction 2015-2030 GA Res 69/283 (2015).

92 United Nations Office for Disaster Risk Reduction Sendai Framework for Disaster Risk Reduction 2015-2030 (2015), art 35.

93195 countries have signed the Agreement and 160 countries have ratified it.

94 Paris Agreement under the United Nations Framework Convention on Climate Change 55 ILM 743 (opened for signature 22 April 2016, entered into force 4 November 2016), art 7 [Paris Agreement].

95 Article 8. 
developing countries with respect to both mitigation and adaptation. ${ }^{96}$ Parties must enhance climate change education, training and public awareness. ${ }^{97}$

While there was criticism that the Paris Agreement did not specifically address human mobility as a result of climate change (or "climate change refugees"), ${ }^{98}$ the UNHCR notes that the Agreement's preamble includes a reference to migrants, ${ }^{99}$ contains references to the protection of people, the resilience of communities and the importance of livelihoods. ${ }^{100}$ Further, when the UN General Assembly adopted the Agreement it also, under the heading "decisions to give effect to the Agreement" requested that the WIM establish a taskforce on displacement to "develop recommendations for integrated approaches to avert, minimize and address displacement related to the adverse impacts of climate change". 101

It is also worth mentioning "The Nansen Initiative", which was aimed at addressing the protection gap for forced cross-border displacement in the context of natural disasters, including those triggered by climate change. ${ }^{102}$ It was recognised that an international convention was not feasible and possibly not even adequate due to regional differences. The aim therefore was to design "a toolbox" of responses, based on a thorough knowledge base about disaster displacement. There was wide consultation throughout the world with both governments and civil society and from this an "Agenda for the Protection of Cross-Border Displaced Persons in the Context of Disasters and Climate Change" was produced and endorsed by over 100 governmental representatives on 14 October 2015. ${ }^{103}$

96 Article 9.

97 Article 12.

98 See for example Advisory Group on Climate Change and Human Mobility Human Mobility in the context of climate change UNFCCC-Paris COP-21 (UNHCR, November 2015); and The Nansen Initiative "Climate change, cross-border displacement and human rights: is there a protection gap and will COP21 help close it?" <www.nanseninitiative.org>.

99 The preamble acknowledges that "climate change is a common concern of humankind, Parties should, when taking action to address climate change, respect, promote and consider their respective obligations on human rights, the right to health, the rights of indigenous peoples, local communities, migrants, children, persons with disabilities and people in vulnerable situations and the right to development, as well as gender equality, empowerment of women and intergenerational equity".

100 See for example Paris Agreement, above n 94, art 7(2).

101 Report of the Conference of the Parties on Its Twenty-First Session, Held in Paris from 30 November to 13 December 2015 UN Doc FCCC/CP/2015/10/Add.1 (29 January 2016) at 4 and 8.

102 The Nansen Initiative "Towards a Protection Agenda for People Displaced Across Borders in the Context of Disasters and the Effects of Climate Change" <www.nanseninitiative.org>.

103 The Nansen Initiative Agenda for the Protection of Cross-Border Displaced Persons in the Context of Disasters and Climate Change (December 2015) vol 1 [Agenda for Protection]; and The Nansen Initiative Global Consultation: Conference Report (December 2015) at 59. 
The Agenda stresses the need for any measures taken to aim:104

... at obtaining full respect for the rights of the individual in accordance with the letter and spirit of

applicable bodies of law, namely human rights law, international humanitarian law and refugee law ...

It sets out a broad set of effective practices that could be used by states and other organisations to ensure a more effective future response to cross-border displacement. It outlines the need for increased preparedness and cooperation, both regional and international, to prevent, avoid and respond to disaster replacement and its causes. It addresses the importance of states avoiding displacement in the first place by building resilience to disasters and conducting planned relocations out of unsafe areas. The Agenda has been followed up by the Platform on Disaster Displacement, which aims to implement the recommendations of the Agenda and build partnerships with stakeholders in order to do so. ${ }^{105}$

The extent of the problem is huge. In 2015 the UNHCR noted that an average of 26.4 million people each year since 2008 had been displaced from their homes by disasters brought on by natural hazards. ${ }^{106}$ This is equivalent to one person being displaced every second. In 2016 more than 24 million people in 118 countries and territories were displaced by natural disasters. ${ }^{107}$ That is three times as many as were displaced by conflict. In 2017, 61 per cent of all new displacements were caused by disasters: a total of 18.8 million displacements across 135 countries. ${ }^{108}$ It is predicted that by 2050 climate change could have displaced up to 200 million people. ${ }^{109}$ Up to 1.7 million of these people are likely to be from the Pacific. ${ }^{110}$ A recent report has estimated that since 1998 to 2017

104 Agenda for Protection, above n 103, at 16.

105 For more, see Platform on Disaster Displacement <www.disasterdisplacement.org >

106 Internal Displacement Monitoring Centre Global Estimates 2015: People displaced by disasters (July 2015) at 8 .

107 Internal Displacement Monitoring Centre Global Report on Internal Displacement 2017 (May 2017) at 31.

108 Internal Displacement Monitoring Centre Global Report on Internal Displacement 2018 (May 2018) at 6-7.

109 Robert McLeman "Climate change, migration and critical international security considerations" (International Organization for Migration Series, 2011) at 13.

110 J Campbell "Climate Change and Population - Movement in Pacific Island Countries" in B Burson (ed) Climate Change and Migration: South Pacific Perspectives (Institute of Policy Studies, Wellington, 2010) 29 at 38. See also Charlie Mitchell "The Angry Sea Will Kill Us All: Our Disappearing Neighbours" (October 2017) Stuff <www.stuff.co.nz> on the impact of climate change in Kiribati. The Prime Minister of New Zealand, Jacinda Arden, and Minister for Climate Change, James Shaw, have indicated that the New Zealand Government will consider creating a new visa category for people displaced by climate change. For more, see Radio New Zealand "NZ considers developing climate change refugee visa" (31 October 2017) <www.radionz.co.nz>; and Mick Krever "New Zealand's new leader: We must be ready for 'climate refugees"' (31 October 2017) CNN International <https://edition.cnn.com>. 
"climate-related and geophysical disasters killed 1.3 million people and left a further 4.4 billion injured, homeless, displaced or in need of emergency assistance". 111

The UN Secretary-General António Guterres has recently said that the people hit first and worst by climate change will be the poor, the vulnerable and the marginalised. ${ }^{112}$ The reasons for the disproportionate effect of both natural disasters and climate change on the poor is the heavy reliance placed on ecological resources. ${ }^{113}$ Given that 70 per cent of the world's poor are women, it is therefore clear that the impacts of climate change will disproportionately affect women. ${ }^{114}$ Women tend to possess fewer assets and rely more on natural resources for their livelihoods. ${ }^{115}$

Agricultural and crop harvests are likely to become more unpredictable and scarce due to climate change. ${ }^{116}$ Women farmers currently account for 50-80 per cent of all food production in the world. ${ }^{117}$ Seventy-nine per cent of women in the Least Developed Countries who are economically active report agriculture as their primary economic activity. ${ }^{118}$ In addition to affecting the livelihood and work of women, decreased food availability is often managed at the expense of the most vulnerable members of a household (women and children), resulting in undernourishment and malnutrition. ${ }^{119}$ Climate change is likely to exacerbate this malnourishment. This, coupled with existing stresses on health, well-being, financial, institutional and human resources, leaves the poor and, thus largely women least able to cope with the impacts of climate change. ${ }^{120}$

111 Centre for Research on the Epidemiology of Disasters Economic losses, poverty \& disasters: 1998-2017 (2018) at 3.

112 António Guterres, Secretary-General of the UN "Climate Action: Mobilizing the World" (speech at the New York University Stern School of Business, New York, 30 May 2017) at 4-5.

113 United Nations Development Programme (UNDP) Overview of linkages between gender and climate change (2013) at 1. See also World Health Organization Gender, Climate Change and Health (2014).

114 International Union for Conservation of Nature (IUCN) Gender and Climate Change - Women as agents of Change (December 2007). There has been criticism that consideration of the disproportionate impact of climate change on women has been ignored in the Paris Agreement. For more, see Taylor Mitchell "Women in Paris: The inclusion of gender considerations in the negotiation and text of the Paris Agreement" [2017] NZWLJ 113

115 UNDP Overview of linkages between gender and climate change (2016) at 4-5.

116 United Nations Economic Commission for Africa Gender and Climate Change-Women matter (March 2009) at 5 .

117 UNDP Gender, climate change and food security (2016) at 3.

118 Food and Agriculture Organization of the United Nations The State of Food and Agriculture (2011).

119 At 5. For example, 50 per cent of women and children and developing countries are already anaemic: see IUCN, above n 114.

120 Food and Agriculture Organization of the United Nations, above n 118, at 1. 
Women and girls are also disproportionately affected by disasters. Women, for example, are less likely to have been taught how to swim so are therefore more vulnerable in severe storms. ${ }^{121}$ This disproportionate effect has been borne out by research. A study by academics at the London School of Economics and the University of Essex examined over 4,600 disasters in 141 countries between 1981 and 2002 and found that women had a higher mortality rate resulting from natural disasters, which was linked to their social and economic position. ${ }^{122}$ For example: in the 1991 cyclone disaster in Bangladesh, 90 per cent of the 140,000 people killed were women. ${ }^{123}$ In the 2004 Asian Tsunami, in many parts of Sri Lanka, Indonesia and India, three times as many women as men died. ${ }^{124}$

\section{STRAINS ON THE CONVENTION}

In 2015, when he was UN High Commissioner for Refugees, António Guterres described the refugee situation as "an unchecked slide into an era in which the scale of global forced displacement as well as the response required is now clearly dwarfing anything seen before". ${ }^{125}$ Apart from the invisible non-entrée policies mentioned above, more active measures have been taken by states in response to the crisis and in some cases in anticipation of a possible crisis.

Some states have erected physical barriers to entry on some parts of their borders, including Turkey, Greece, Bulgaria, Macedonia, France and Hungary. Europe will soon have more physical barriers on its national borders than it did in the Cold War. ${ }^{126}$ Some states try to intercept individuals at sea prior to them entering the jurisdiction, ${ }^{127}$ while others have policies of detaining for lengthy periods everyone who arrives at the borders, particularly in mass arrivals. ${ }^{128}$ There have been

121 E Neumayer and T Plümper "The Gendered Nature of Natural Disasters: The Impact of Catastrophic Events on the Gender Gap in Life Expectancy, 1981-2002" (2007) 97 Annals of the Association of American Geographers 551 .

122 At 555.

123 Keiko Ikeda "Gender Differences in Human Loss and Vulnerability in Natural Disasters: A Case Study from Bangladesh" (1995) 2 Indian Journal of Gender Studies 171.

124 Oxfam International "The Tsunami's Impact on Women" (March 2005) <www.oxfam.org.uk>

125 UNHCR "Worldwide displacement hits all-time high as war and persecution increase" (18 June 2015) <www.unhcr.org>.

126 See The Data Team "More neighbours make more fences" The Economist (online ed, London, 7 January 2017).

127 See for example Andreas Schloenhardt and Colin Craig "'Turning Back the Boats': Australia's Interdiction of Irregular Migrants at Sea" (2015) 27 IJRL 536.

128 For example ss 317A-319 of the Immigration Act 2009 (NZ). For a summary of the opposition to this measure see Christopher Foulkes "The Shafts of Strife and War: A Critical Analysis of the Immigration (Mass Arrivals) Amendment Bill" (2012) 43 VUWLR 547. On the issue of mass arrivals generally see Institut de Droit International Mass Migrations: Final Resolution (Session de Hyderabad, 9 September 2017). 
agreements to send refugees to other jurisdictions to have their claims determined. ${ }^{129}$ Some states will refuse recognition as refugees to those who have been afforded some sort of protection in a third country or who had the ability to claim asylum in a safe country. ${ }^{130}$ This is on the basis that any secondary movement is purely for migration purposes. ${ }^{131}$

Many of these measures are contrary to the Convention obligations. A good faith understanding of the duty of non-refoulement requires states to provide refugees with reasonable access to the territory of a state party to the Convention. The erection of physical barriers stopping entry into a state breaches this obligation. ${ }^{132}$ The exception for reasons of national security was only added to the Convention at the "latest possible stage" and should be interpreted restrictively to allow for removal of those who threaten the country of the asylum (assessed on an individual basis), rather than allowing for "broad-based refusal to give access to asylum proceedings". 133

Interception at sea risks breaching non-refoulement obligations and can be dangerous where vessels are unsafe. ${ }^{134}$ The responsibility of a state begins not on the physical border but rather where the state jurisdiction begins. ${ }^{135}$ It has been held that this jurisdiction has extraterritorial reach

129 See for example Monique Failla "Outsourcing Obligations to Developing Nations: Australia's Refugee Agreement with Cambodia" (2016) 42 Monash U L Rev 638.

130 See for example ss 134 and 137-138 of the Immigration Act, which incorporate the concept of "third countries".

131 GS Goodwin-Gill and J McAdam The Refugee in International Law (3rd ed, Oxford University Press, Oxford, 2010) at 391.

132 See also The Eighth Colloquium on Challenges in International Refugee Law The Michigan Guidelines on Refugee Freedom of Movement (2018) 39 Mich J Intl L 5 at [10]. These Guidelines accept that any derogation from the duty of non-refoulement can only be justified in extreme cases of mass influx and only when the state has not contributed to the peril: at [12]-[13]. For more on the use of non-refoulement and non-entrée policies, see Thomas Gammeltoft-Hansen and James Hathaway "Non-refoulement in a World of Cooperative Deterrence" (2015) 53 Col J of Transnational L 235.

133 Leiserson, above n 72, at 201-206. See also UNHCR The Refugee Convention, 1951: The Travaux Préparatoires Analysed with a Commentary by Dr Paul Weis (1990) at 240.

134 As to the legal issues surrounding this, see Guy Goodwin-Gill "The Right to Seek Asylum: Interception at Sea and the Principle of Non-Refoulement" (2011) 23 IJRL L 443. There is also a duty to render assistance at sea pursuant to United Nations Convention on the Law of the Sea 1833 UNTS 3 (opened for signature 10 December 1982, entered into force 16 November 1994) [UNCLOS], art 98(1).

135 A vessel sailing on the high seas is subject to the exclusive jurisdiction of the state of the flag it is flying: UNCLOS, art 92. 
extending to the situation where a person is under the continuous and exclusive control of agents of the state. ${ }^{136}$ Interception in such a case therefore occurs within the territory of the state. ${ }^{137}$

Detention in the earliest moments of arrival at a border may not be arbitrary but any further detention should be justified on a continuous and individual basis. ${ }^{138}$ It can be in accordance with obligations under the Convention to send refugees to another jurisdiction to have their claims determined but this is only where it is clear that all of the protections under the Convention would be accorded to them, as well as any other human rights obligations fulfilled. ${ }^{139}$

Where parties to the Convention employ plainly unlawful mechanisms or those of dubious legality to try and avoid their obligations under the Convention, this weakens the Convention and any customary international law deriving from it. This includes the customary international law duty of non-refoulement. ${ }^{140}$ Even if states take measures to deter refugees that are not in breach of the Convention, they risk creating resentment from the developing nations currently hosting the bulk of those displaced.

It has been suggested that the current refugee crisis, in combination with the rise of terrorism, requires re-examination of the Convention or overlooking breaches of duties owed by Contracting

136 See for example Jamaa v Italy (2012) 55 EHRR 21 (ECHR). While this decision turned on the direct involvement of Italian ships and sailors, it is part of a wider trend recognising extraterritorial application of refugee protection responsibilities: see Gammeltoft-Hansen and Hathaway, above n 132, at 263-266.

137 For more, see Delphine Nakache and Jessica Losier "The European Union Immigration Agreement with Libya: Out of Sight, Out of Mind?" (25 July 2017) E-International Relations <www.e-ir.info>.

138 The term detention is used to "signify confinement in prison, closed camp, or other restricted area, such as a 'reception' or 'holding centre'": Guy S Goodwin-Gill "Article 31 of the 1951 Convention Relating to the Status of Refugees: non-penalization, detention and protection" in Erika Feller, Volker Türk and Frances Nicholson (eds) Refugee Protection in International Law: UNHCR's Global Consultations on International Protection (Cambridge University Press, Cambridge, 2003) 185 at 220. See The Michigan Guidelines on Refugee Freedom of Movement, above n 132, at [14]-[16]. Nor shall a state routinely subject refugees to restrictions on liberty less intrusive than detention: at [17].

139 For more, see The Fourth Colloquium on Challenges in International Refugee Law The Michigan Guidelines on Protection Elsewhere (2006) 28 Mich J Intl Law 207. For criticism of the Australian approach to this, see Monique Failla, above n 129. The approach in Europe is discussed below.

140 On the 50th anniversary of the Convention, States acknowledged the continuing relevance and resilience of the "international regime of rights and principles, including at its core the principle of non-refoulement, whose applicability is embedded in customary international law": Declaration of States parties to the 1951 Convention and/or its 1967 Protocol Relating to the Status of Refugees, Ministerial Meeting of States Parties, Geneva, Switzerland 12-13 December 2001 UN Doc HCR/MMSP/2001/09 (16 January 2002) at [4]. The Declaration was welcomed by the UN General Assembly: Office of the United Nations High Commissioner for Refugees GA Res 57/187 (2001) at [3]. 
States. ${ }^{141}$ This implies that the Convention was not designed to handle a large refugee crisis. However, this has been disputed. ${ }^{142}$ A cynical view is that the former viewpoint has only been raised since the refugee crisis hit Europe, while developing countries have been dealing with mass influxes of refugees for years. ${ }^{143}$ Even if the Convention was not designed to deal with mass movements, this is not a proper justification for breaching it. States have a duty to uphold and abide by the law, in accordance with the rule of law. ${ }^{144}$

The aim of the Convention was to encourage the collaboration of states to admit refugees, not to collaborate to deny entry. ${ }^{145}$ Collaboration has worked in the past. For example, in the Hungarian refugee crisis of 1956, 100,000 refugees were resettled in the first 10 weeks. ${ }^{146}$ There was some cherry picking. Portugal and Denmark offered resettlement only to mothers and children, while other states preferred to accept refugees who would be productive members of the economy. ${ }^{147}$ Nevertheless, while admission was not automatic, it was "not a hotly contested issue". ${ }^{148}$

\section{ARRANGEMENTS IN EUROPE}

I now discuss some of the measures taken in Europe in order to provide a case study of measures taken by a group of nations to deal with the refugee issue.

\section{A Allocation of Responsibility}

The regime for dealing with refugee claims in the European Union (EU) began with the Dublin Convention that was signed on 15 June 1990 and was replaced by the Dublin II Regulation in 2003

141 See for example David A Martin "Immigration's Enigma Principle: Protection and Paradox" (Virginia Public Law and Legal Theory Research Paper No 63, November 2015). For more on the policies introduced by countries to limit terrorism and the impact on the Convention, see Alice Farmer "Non-refoulement and jus cogens: limiting anti-terror measures that threaten refugee protection" (2008) 23 Geo Immigr LJ 18; and Thomas F Lampert "Prioritizing National Security at the Expense of Refugee Rights: The Effects of $H T v$ Land Baden-Wurttenberg" (2017) 40 BC Intl and Comp L Rev 14.

142 Marjoleine Zieck "Refugees and the Right to Freedom of Movement: From Flight to Return" (2018) 39 Mitch J Intl L 19 at 21-22.

143 At 22 .

144 At $21-22$.

145 Leiserson, above $n$ 72, at 199-206. It has also been argued that refugee deterrence policies can infringe on civil liberties of the citizens of the state: see Ormsby, above n 66.

146 Rupert Colville "Fiftieth Anniversary of the Hungarian uprising and refugee crisis" (23 October 2006) UNHCR <www.unhcr.org>. See also Leiserson, above n 72, at 206.

147 Leiserson, above n 72, at 206. See also Marjoleine Zieck "The 1956 Hungarian Refugee Emergency, An Early and Instructive Case of Resettlement" (2013) 5 Amsterdam Law Forum 45 at 54-56.

148 Leiserson, above n 72, at 207. 
and the Dublin III Regulation from January $2014 .{ }^{149}$ It is a process for assigning responsibility for processing an asylum application to a particular member state. The most frequently used criterion for determining this is the member state through which the applicant first entered the EU.

This system has been under strain in the current crisis. ${ }^{150}$ In 2011 refugees returned to Greece in accordance with this system ceased after two court decisions concluded that Greece's refugee system had systemic deficiencies. ${ }^{151}$ While Greece did make major efforts to improve its systems, they continue to be under major strain with the large influx of refugees. ${ }^{152}$

Burden sharing arrangements between Member States have not, however, been a success. ${ }^{153}$ The European Commission has launched infringement procedures against the Czech Republic, Hungary and Poland for non-compliance with the obligations created under a 2015 Council Decision in which Member States committed to relocate refugees from the primary receiving states of Italy and Greece. ${ }^{154}$ These obligations include pledging available relocations every three months. Hungary has not taken any action since the scheme began. Poland and the Czech Republic have taken no action since December 2015 and August 2016 respectively. ${ }^{155}$

149 Convention determining the State responsible for examining applications for asylum lodged in one of the Member States of the European Communities [1997] OJ C254 (signed 15 June 1990, entered into force 1 September 1990) [Dublin Convention]; Regulation 343/2003 establishing the criteria and mechanisms for determining the Member State responsible for examining an asylum application lodged in one of the Member States by a third-country national [2003] OJ L50/1 [Dublin II Regulation]; and Regulation 604/2013 establishing the criteria and mechanisms for determining the Member State responsible for examining an application for international protection lodged in one of the Member States by a third-country national or a stateless person (recast) [2013] OJ L180/31 [Dublin III Regulation].

150 For more, see Susan Fratke Not Adding Up: The Fading Promise of Europe's Dublin System (Migration Policy Institute, March 2015).

151 MSS v Belgium and Greece (2011) 53 EHRR 2 (ECHR); and C-411/10 and C-493/10 Joined cases of NS v United Kingdom and MEv Ireland [2011] ECR 0.

152 Greece had support for its systems from the EU in the form of over $€ 352$ million in emergency assistance since the beginning of 2015 , in addition to the $€ 509$ million already allocated to Greece under the national programmes for 2014-2020: see European Commission Managing the Refugee Crisis: EU Financial Support to Greece (5 October 2016).

153 See Library of Congress "Refugee Law and Policy: Greece" (21 June 2016) <www.loc.gov>.

154 European Commission "Relocation: Commission launches infringement procedures against the Czech Republic, Hungary and Poland" (press release, 14 June 2017). Institut de Droit International, above n 128, includes reference to the burden-sharing required in the management of mass migration in pt 6 and in particular recognises that this requires solidarity of states, taking into account their geographical situation, capacities and resources: art 17.

155 See European Commission, above n 154. On 7 December 2017 the European Commission announced that these Member States had been referred to the Court of Justice of the European Union: see European Commission "Relocation: Commission refers the Czech Republic, Hungary and Poland to the Court of 


\section{B Agreement with Turkey}

The EU has also made arrangements with states outside Europe. Turkey has been a key partner in these arrangements. A Joint Action Plan was agreed in October 2015 to "confront and surmount the existing challenges [of the refugee crisis] in a concerted manner". ${ }^{156}$ The Plan outlined cooperation across two areas: providing humanitarian assistance to Syrian refugees in Turkey and preventing "irregular migration" to the EU. This was followed up a month later with an agreement to pay $€ 3$ billion to fund Turkish border security efforts. ${ }^{157}$

In March 2016 the EU and Turkey agreed on a statement which committed Turkey to accept the return of all "irregular migrants" crossing from Turkey into Greece, after an individual assessment of their asylum claims by the Greek authorities. ${ }^{158}$ This assessment was to take place "in full accordance with EU and international law, thus excluding any kind of collective expulsion". Further, all would be "protected [both before and after return to Turkey] in accordance with the relevant international standards and in respect of the principle of non-refoulement". This was said to be a "temporary and extraordinary measure" necessary to "end the human suffering and restore public order".

For every Syrian returned to Turkey from the Greek Islands, another Syrian would be resettled in the EU. Priority for this resettlement was to be given "to migrants who have not previously entered or tried to enter the EU irregularly". The earlier agreement which allocated $€ 3$ billion for refugees in Turkey was to be brought forward and, upon its exhaustion, additional funding of up to $€ 3$ billion would be mobilised from the EU.

The legality of such an agreement - including whether Turkey is a "safe third country" for refugees and therefore whether it is a breach of the Convention to send them back there - has been debated. ${ }^{159}$ The legality of the asylum seeking determination has also been criticised. It has been said that in

Justice" (press release, 7 December 2017). The recent election win of the conservative government in Hungary makes it unlikely that this position will change: see Nick Thorpe "Hungary's dominant leader Orban defiant on keeping migrants out" (29 April 2018) BBC News <www.bbc.com>.

156 European Commission "EU-Turkey Joint Action Plan" (press release, 15 October 2015).

157 Valentina Pop "EU to pay \$3 Billion for Turkey's Help in Stemming Migrant Crisis" Wall Street Journal (online ed, New York, 12 November 2015). For more, see Leiserson, above n 72, at 209.

158 This was at the third meeting since November 2015 intended to "deepen Turkey-EU relations" and also address the migration crisis: European Council "EU-Turkey statement" (press release, 18 March 2016).

159 See for example the allegations made by Amnesty International that Turkish authorities on a near daily basis force the return of around 100 Syrian men, women and children to Syria: Amnesty International "Turkey: Illegal Mass Returns of Syrian Refugees Expose Fatal Flaws in EU-Turkey Deal" (press release, 1 April 2016). See also Leiserson, above n 72, at 211-213. 
reality the assessment is "not a person's individual need for international protection, but only whether he or she can be returned to Turkey". ${ }^{160}$

Another potential issue is the focus on Syrian refugees for the 1:1 resettlement agreement and the potential for discrimination. The safety and conditions of asylum seekers in Greece while they wait for their assessment is also a matter for concern. There are reports that medical checks and other assessments to identify and protect vulnerable people outlined in Greek law are not consistently applied. ${ }^{161}$ At its peak, there were 16,000 people in facilities with a capacity for $9,000 .{ }^{162}$

The final element of this agreement that has raised questions is its legal status. ${ }^{163}$ In April 2016, two asylum seekers brought an action in the General Court of the EU, alleging that the agreement with Turkey was unlawful. In February 2017, the Court held that it lacked jurisdiction to hear the claim because the EU was not a party to the agreement: it had been concluded (despite the press statements referred to above) solely between the Member States in their own right and Turkey. ${ }^{164}$ The Court also doubted whether a binding international agreement could have been formed through such an informal process.

Appeals against the decision were dismissed by the Court of Justice, ${ }^{165}$ on the basis that the appeals were incoherent and made general assertions without "indicating the requisite degree of precision". ${ }^{166}$ It was also noted that the appeals did not pertain to any error of law. ${ }^{167}$

160 International Rescue Committee, Norwegian Refugee Council and Oxfam The Reality of the EU-Turkey Statement (17 March 2017) at 2.

161 Doctors without Borders One year on from the EU-Turkey Deal: Challenging the EU's Alternative Facts (March 2017) at 17; and European Council on Refugees and Exiles "Greece amends its asylum law after multiple Appeals Board decisions overturn the presumption of Turkey as a 'safe third country'" (24 June 2016) <www.ecre.org>.

162 International Rescue Committee, Norwegian Refugee Council and Oxfam, above n 160, at 6.

163 Carmelo Danisi "Taking the 'Union' out of 'EU': The EU-Turkey Statement on the Syrian Refugee Crisis as an Agreement Between States under International Law" (20 April 2017) Blog of the European Journal of International Law <www.ejitalk.org>.

164 Case T-192/16 NF v European Council ECLI:EU:T:2017:128 at [69]-[71].

165 C-208/17P NF v European Council ECLI:EU:C:2018:705.

166 At [16]-[18].

167 At [18]-[30]. 


\section{Libya Agreement}

In February 2017 the Italian government signed a memorandum of understanding with the new UN-backed Libyan government to combat illegal immigration, human trafficking and contraband. ${ }^{168}$ This is a continuation of a 2008 treaty between Libya and Italy, which had been suspended in 2011 (when the North Atlantic Treaty Organization began bombing Libya). ${ }^{169}$ It involves funding to intercept migrant boats, to train the national coast guard and other agencies, and to enhance the border control of Libya and its neighbouring countries. It also includes support of refugee camps in Libya and aid in the voluntary repatriation of refugees willing to return to their countries of origin, as well as development aid. ${ }^{170}$

The Italian agreement with Libya was endorsed by the EU in its Malta Declaration of the next day. ${ }^{171}$ The Malta Declaration outlines a joint EU and Libyan effort to "significantly reduce migratory flows along the Central Mediterranean route and break the business model of smugglers". ${ }^{172}$ The steps proposed mirror those in the Italian-Libyan agreement. As well, the Council indicated its intention to address "potential barriers, for example in relation to conditions to be met for returns, and [to] reinforce EU return capacities, while respecting international law". ${ }^{173}$

The Malta Declaration has been heavily criticised because of Libya's continuing political instability and the major human rights breaches in its detention centres, ${ }^{174}$ which house all who do not have valid travel authorisations, including refugees. ${ }^{175}$ Conditions in such detention centres are "generally inhuman: severely overcrowded, without adequate access to toilets or washing facilities,

168 Memorandum of Understanding Italy-Libya (2 February 2017).

169 The Treaty of Friendship, Partnership, and Cooperation between the Italian Republic and Great Socialist People's Libyan Arab Jamahiriya (signed 30 August 2008).

170 There have been allegations (on which I do not comment) that the Italian Government has dealt directly with groups involved in smuggling migrants - paying them to not sail to Europe. See for example Bel Trew "Militias fight over Italian cash meant to stop migrant flow from Libya" The Times (online ed, London, 10 October 2017). Similar accusations have been made in the past against Australian officials: see Amnesty International By Hook or By Crook: Australia's Abuse of Asylum-Seekers at Sea (October 2015) at ch 2.

171 European Council "Malta Declaration by the members of the European Council on the external aspects of migration: addressing the Central Mediterranean route" (press release, 3 February 2017).

172 European Council, above n 171.

173 European Council, above n 171.

174 See Nakache and Losier, above n 137.

175 United Nations Support Mission in Libya and Office of the United Nations High Commissioner for Human Rights "Detained and Dehumanised": Report on Human Rights Abuses Against Migrants in Libya (13 December 2016). 
food, or clean water". ${ }^{176}$ Those confined to them are subjected to "arbitrary detention, torture, other ill-treatment, unlawful killings, sexual exploitation, and a host of other human rights abuses". ${ }^{177}$

The agreement may not, in fact, relieve the EU of responsibility. Thomas Gammeltoft-Hansen and Professor James Hathaway have argued that acts of "co-operative deterrence" can make destination states liable for the action of other states where they aid or assist breaches of international law (such as the duty of non-refoulement). ${ }^{178}$ They see this as applying to a "state which takes steps such as providing maritime patrol vessels or border control equipment, which seconds border officials, or which shares relevant intelligence or directly funds migration control efforts". ${ }^{179}$ The agreements with Libya could fall into this category. ${ }^{180}$

\section{Other Measures}

It is worth acknowledging the difficulties a state faces in returning individuals who are determined by that state not to be refugees to their countries of origin. ${ }^{181}$ It has been suggested that such migrants have a 73 per cent chance of remaining in Europe even if served with an order to leave. ${ }^{182}$

Against this background, the EU has entered into immigration agreements with Northern African countries, such as Morocco and Tunisia, designed to stem migration flows by providing aid to reinforce capacities in border management and also to ensure their cooperation in taking back their own national irregular migrants from Europe. The EU is seeking similar agreements with other African countries, including Nigeria and Ethiopia. ${ }^{183}$

Of course, the difficulty with many of these measures is that they will also affect the ability of refugees to reach Europe and effectively push the issue back to neighbouring developing countries in Africa. This may additionally give rise to human rights concerns, as the situation in Libya

176 At 1.

177 At 1.

178 Gammeltoft-Hansen and Hathaway, above n 132.

179 At 279.

180 Leiserson, above n 72, at 211-213, considers that this analysis could also be applicable to the agreements with Turkey.

181 Considering the dangers of travel (outlined above), there must be very strong push factors that drive people to take the risk of leaving their country of origin and attempt to seek asylum overseas. This was recognised in the New York Declaration, above n 39.

182 According to "official statistics" cited by Bruno Waterfield, Catherine Philip and Richard Ford "EU's failure over illegal migrants fuels crisis" The Times (online ed, London, 24 August 2017).

183 Nakache and Losier, above n 137, refer to this as the "externalisation" of the EU's borders. 
demonstrates. Worryingly, there have been threats to cut off development aid from states that refuse to accept and facilitate the return of their nationals. ${ }^{184}$

More positively, there has been a recognition by European leaders that improving the lives of those in developing countries will help stem the flow of refugees and migrants. Speaking at the G20 Africa Partnership Summit, German Chancellor Angela Merkel said that a compact with Africa to combat poverty and climate change was the best way to enhance European security and would allow the EU to "put a stop to the activities of criminals who are toying with refugees and migrants' fates". ${ }^{185}$ Initiatives like this dovetail with the UN's Sustainable Development Goals adopted in September 2015. But, of course, they are long-term aspirations that can only be realised through prolonged and coordinated effort. They have less impact in the short-term.

\section{THE NEW YORK DECLARATION FOR REFUGEES AND MIGRANTS}

Moving now to the world stage, the UN General Assembly decided in December 2015 that a high level plenary meeting would be held on 19 September 2016 to address the issue of large movements of refuges and migrants. ${ }^{186}$ The then Secretary-General, Ban Ki-moon, was instructed to complete a report for that meeting. In that report, he said that it was a "global priority" that there be a "greater sharing of responsibilities" for refugees in order to safeguard the rights of refugees and to ensure that "the impact of their flight is not borne disproportionately by some countries and regions on the basis of their proximity to countries of origin alone". ${ }^{187}$ Responsibility-sharing by Member States should also extend to admission of up to 10 per cent of refugees by non-current recipient states. ${ }^{188}$ This would provide alternatives to irregular and often dangerous journeys. He recommended a global compact to this effect. It was recognised that in a crisis situation: ${ }^{189}$

... until the attainment of durable solutions, investments must be made in the capacities of refugees, local authorities and community-based systems and networks, in particular, for the protection of women and children.

184 Carassava and Philp, above n 70.

185 Angela Merkel, Chancellor of Germany (speech at the G20 Africa Partnership - investing in a common future conference, Berlin, 12 June 2017).

186 High-level plenary meeting of the General Assembly on addressing large movements of refugees and migrants GA Res 70/290 (2016).

187 Ban Ki-moon, United Nations Secretary-General In safety and dignity: addressing large movements of refugees and migrants UN Doc A/70/59 (21 April 2016) at [68].

188 At [83].

189 At [76]. 
With regard to migrants in general, the Secretary-General noted that while "poverty acts as a driver of migration, the poorest often lack the resources to migrate". ${ }^{190}$ Thus, while economic development would reduce migration pressures in the long-term, it often would increase them in the short-term. Meeting the Sustainable Development Goals was nonetheless key, as in the short-term this would "provide for well-managed migration policies, lower the costs of migration, and strengthen the contribution of migrants" to their communities. ${ }^{191}$

On Monday 19 September 2016, the UN Summit for Refugees and Migrants was held in New York. That day, the New York Declaration was adopted by the General Assembly. ${ }^{192}$ While recognising that refugees and migrants are governed by separate legal frameworks, the Declaration acknowledged that both groups have the same universal human rights and fundamental freedoms and share common challenges and vulnerabilities. ${ }^{193}$ It also acknowledged the positive contribution made by safe, orderly and regular migration to inclusive growth and sustainable development. ${ }^{194}$

Addressing "large movements" of refugees and migrants, ${ }^{195}$ the Declaration says that such movements are "global phenomena that call for global approaches and global solutions" but that currently neighbouring or transit countries, which are normally developing countries, are disproportionately affected. ${ }^{196}$ Member States acknowledged a "shared responsibility" to manage large movements through international cooperation "in a humane, sensitive, compassionate and people-centred manner". 197 This requires "comprehensive policy support, assistance and protection". ${ }^{198}$ There must also be a commitment to find long-term and sustainable solutions which combat the "abuses and exploitation suffered by countless refugees and migrants in vulnerable situations". ${ }^{199}$ The root causes of large movements of refugees and migrants must also be

190 At [24].

191 At [45].

192 New York Declaration, above n 39.

193 At [5]-[6].

194 At [4].

195 Defined to be "understood to reflect a number of considerations, including: the number of people arriving, the economic, social and geographical context, the capacity of a receiving State to respond and the impact of a movement that is sudden or prolonged. The term does not, for example, cover regular flows of migrants from one country to another": at [6]

196 At [7].

197 At [11].

198 At [11].

199 At [10]. 
addressed. ${ }^{200}$ Finally, the Declaration calls for support from governments, private parties and the civil sector to help combat the concerning "xenophobic and racist responses to refugees and migrants" exhibited in many parts of the world. ${ }^{201}$

Commitments were entered into that affect both migrants and refugees, including:

(a) the implementation of border control procedures in conformity with applicable obligations under international law, including international human rights law and international refugee law (while recognising that states have rights and responsibilities to manage and control their borders); 202

(b) addressing the unsafe movements of refugees and migrants; ${ }^{203}$ and

(c) pursuing alternatives to detention while assessment of legal status is under way, especially when children are involved. ${ }^{204}$

There are commitments specifically for refugees, including addressing the root causes of crisis situations and the prevention or resolution of conflict by peaceful means. ${ }^{205}$ The commitment to the Refugee Convention was reaffirmed, including the non-refoulement obligation. ${ }^{206}$ There was also a commitment to a more equitable sharing of the burden and responsibility for hosting and supporting the world's refugees, while taking account of existing contributions and the differing capacities and resources among states. ${ }^{207}$ The expansion of legal pathways available for refugees to be admitted to or resettled in third countries is to be expanded, including resettlement programmes. ${ }^{208}$ The significant gap between the needs of refugees and available resources was noted, as was the importance of civil society as a key partner in response to this. ${ }^{209}$

There were also commitments specifically related to migrants. These were primarily aimed at "addressing the drivers that create or exacerbate large movements" with the goal that migration would

200 At [12].

201 At [13]-[15].

202 At [24].

203 At [27].

204 At [33].

205 At [64].

206 At [65] and [67].

207 At [68].

208 At [77]-[78].

209 At [86]. 
be "a choice, not a necessity". ${ }^{210}$ The Declaration recognised the "positive and profound contributions" made by migrants to both countries of origin and destination states ${ }^{211}$ and called for more integrated and strengthened global governance of migration. ${ }^{212}$ The commitments were softened somewhat, however, by the acknowledgement that "each State has a sovereign right to determine whom to admit to its territory". 213

Annex 1 to the Declaration contained a "Comprehensive Refugee Response Framework". This was to provide a basis for more specific frameworks to be developed by the Office of the UNHCR "for each situation involving large movements of refugees". ${ }^{214}$ In 2018 the High Commissioner for Refugees in his 2018 annual report presented a Global Compact on Refugees to the United Nations. ${ }^{215}$ The objectives are to: ease pressures on host countries; enhance refugee self-reliance; expand access to third country solutions; and support conditions in countries of origin for return in safety and dignity. ${ }^{216}$ The Compact further states that these objectives will be achieved "through the mobilization of political will, a broadened base of support, and arrangements that facilitate more equitable, sustained and predictable contributions among States and other relevant stakeholders". ${ }^{217}$

Part III of the Global Compact sets out a programme of action identifying areas in need of support and arrangements for burden and responsibility sharing. ${ }^{218}$ The programme of action is underpinned by a "partnership and participatory approach" with a special focus on ending sexual exploitation and human trafficking. ${ }^{219}$

Although the Global Compact is not legally binding, it is said to represent the political will and ambition of the international community as a whole for strengthened cooperation and solidarity with

210 At [43].

211 At [46].

212 At [47]-[49].

213 At [42].

214 At [69].

215 UNHCR Report of the United Nations High Commissioner for Refugees: Part I-Covering the period 1 July 2017-30 June 2018 UN Doc A/73/12 (Part I) (17 August 2018); and UNHCR Report of the United Nations High Commissioner for Refugees: Part 2 - Global compact on refugees UN Doc A/73/12 (Part II) (13 September 2018) [UNHCR Global compact on refugees].

216 UNHCR Global compact on refugees, above n 215, at Part 1, C, [7].

217 At Part 1, C, [7].

218 At Part III, [11]-[13].

219 At Part III, [13]. 
refugees and affected host countries. It will be "operationalized through voluntary contributions to achieve collective outcomes and progress towards its objectives".

Separately, a Global Compact for Safe, Orderly and Regular Migration has been developed and the General Assembly will hold an intergovernmental conference in December 2018 with a view of adopting the Migration Compact. ${ }^{220}$ If it is adopted, the Migration Compact will involve the creation of a new framework (since none currently governs non-refugee migration). However, it will also be non-binding. Rather, it "fosters international cooperation among all relevant actors on migration, acknowledging that no state can address migration alone" and it continues to uphold the sovereignty of states. ${ }^{221}$ Guidelines for the treatment of migrants in vulnerable situations, including unaccompanied children have also been developed. ${ }^{222}$

There have been criticisms of the New York Declaration. The exclusion of internally displaced peoples ${ }^{223}$ has been described as a "strategic mistake" which is "symptomatic of the ever-growing disparity between the scale of internal displacement worldwide and the lack of global focus on [the issue of] protecting and assisting [internally displaced persons]". 224 A joint statement issued by some 26 non-governmental organisations (including Amnesty International, Oxfam and Refugees International) described the Declaration as "nowhere near enough", noting "uneven commitments", a "lack of urgency" and language that "attempts to back-slide on or undercut existing fundamental human rights standards". 225

Although many of the criticisms levied towards the Declaration centre on the fact that it is not legally binding, it remains a step forward nevertheless, even if only taken after a refugee crisis that

220 International Organization for Migration "Global Compact for Migration" <www.iom.int>.

221 Global Compact for Safe, Orderly and Regular Migration (Final Draft, July 2018) at [7].

222 Global Migration Group Principles and Guidelines, supported by practical guidance on the human rights, protection of migrants in vulnerable situations (2018).

223 The New York Declaration does mention internally displaced persons (at [20]), but this is in the context of the possibility of them crossing borders to "seek protection and assistance in other countries as refugees or migrants". The Declaration does, however, note the need for "reflection on effective strategies" to protect internally displaced persons and to prevent such displacement: at [20].

224 Alexander Bilak "Missing the heart of the problem: Why ignoring internal displacement undermines the purpose of the UN summit on migrants and refugees" (16 September 2016) Thomson Reuters Foundation News <http://news.trust.org>. It has been suggested that the requirement of alienage, that an individual must have left their state of origin to classify as a refugee, is because the definition of refugee is tied to the ability of a state to discharge its obligations under the Convention. The requirement of alienage is a practical constraint that respects state sovereignty. See James Hathaway and Michelle Foster The Law of Refugee Status (2nd ed, Cambridge University Press, Cambridge, 2014) at 22.

225 Amnesty International and others "Rising to the challenge: World leaders need to urgently adopt solutions for refugees and migrants beyond the UN Summit" (September 2016) <www.amnesty.eu>. 
had long affected many African states before it reached Europe's shores. It recognises the need for action and may exert moral force. There is reason to doubt whether, in the current political climate, true burden sharing (as envisaged by the Secretary-General in his report) could have been achieved. Compared with when the 1951 Refugee Convention was signed, even skilled workers are more likely to lack job security and there is less demand for low-skilled labour (both because of rising automation and the ability to outsource production to low-wage economies). This, coupled with fears of terrorism, has created a climate of hostility towards refugees and migrants in many states. Overcoming this will not be easy, particularly in the short-term.

As has been noted by academics discussing the "muted" nature of the New York Declaration, "those States with the greatest capacity to protect refugees tend to have the least political will to do so". ${ }^{226}$ Even if wealthy western states had agreed to burden sharing measures, they likely would have "cherry-picked" high-skilled refugees, or those with a similar religion and cultural practices to the existing population.

Probably in recognition of the long-term nature of solutions which may arise from the Declaration, on 20 September 2015 the Secretary-General and seven other Member States co-hosted a summit to "increase global responsibility sharing for refugees worldwide and thereby strengthen the international community's capacity to address mass displacement". ${ }^{227}$ In summary, some 52 leaders and senior officials, including 32 heads of state or government, pledged to increase multilateral humanitarian assistance by approximately USD 4.5 billion over 2015 levels. ${ }^{228}$ The combined pledges roughly doubled the total number of refugees afforded lawful admission into third countries.

The situation is not going to improve without decisive action. Displacing events, such as natural disasters and conflict, are not going to go away in the foreseeable future. Climate change will also likely exacerbate the existing position. Ultimately, the best way to reduce forced migration and the harmful effects it has on both individuals and states is to secure sustainable development for vulnerable countries. As the Secretary-General noted in his April 2016 report, this will not only reduce migration pressures in the long run but will also help receiving states handle influxes of people in the short-term. ${ }^{229}$ It is also likely to be more politically palatable for developed countries - which have demonstrated a far greater willingness to provide financial assistance to than to take on migrants themselves ${ }^{230}$ - and hence more achievable in the current political climate. Care must be taken,

226 Rebecca Dowd and Jane McAdam "International Cooperation and Responsibility - Sharing to Protect Refugees: What, Why and How?" (2017) 66 ICLQ 864 at 890.

227 UNHCR Summary Overview Document: Leaders' Summit on Refugees (November 2016).

228 The exact currency was not specified in the Summary Overview Document however it is assumed to be USD as the Leaders' Summit on Refugees was held in New York.

229 Ki-moon, above n 187, at [24].

230 Dowd and McAdam, above n 226, at 877. 
however, to ensure that aid translates into sustainable development, and is not misused or directed towards efforts to keep refugees away.

\section{SO WHERE DOES THIS LEAVE THE CONVENTION?}

It has been suggested that a major strength of the Convention is its ability to adapt to new forms and targets of persecution and non-state perpetrators. This has allowed the definition of refugee to be "continuously adapted" to meet new circumstances. ${ }^{231}$ I agree that the Convention has theoretically adapted to issues of gender for example, but this does not mean that all those who meet the definition of refugee are able to take advantage of its protections.

In practical terms, in order to take advantage of the protections of the Convention, a person must reach the territory of a state party to the Convention. Some (and often arguably those most in need of assistance) are unable to leave their country or indeed, in cases of intimate partner violence, leave the perpetrator. Even if they are able to leave, normal safe transport options are usually unavailable.

Further, there are many individuals currently at risk of serious harm who do not come within the Convention at all. Internally displaced people are not covered by the Convention. Nor is it likely that those displaced by natural disasters or climate change will come within the Convention unless they also separately fall within a Convention ground.

These issues have a gender perspective. Women are disproportionally represented in the groups either excluded from the Convention altogether or those who, despite being persecuted on Convention grounds, are unable to take advantage of it. This puts them at particular risk of exploitation including sextortion 232 and trafficking. Simply expanding the definition in the Convention to include gender has not sufficed to protect the most vulnerable.

The scale of displacement by the end of 2017 (both for refugees and for those not covered by the Convention) was higher than that experienced in the aftermath of the Second World War and the rate of increase is not expected to ease significantly, at least in the short-term. Far too many (including children) become long-term residents in refugee camps, where living conditions are poor and where there are risks of disease, abuse and trafficking.

The issue arises whether this means that the Convention should be abandoned or renegotiated. Professor Jane McAdam does not consider it should be abandoned. She points out that, while the Convention does not protect every displaced person, it was not designed to and it still protects those who come within it. ${ }^{233}$ This applies, however, only if refugees manage to reach a state that is both

231 Andrew I Schoenholtz "The New Refugees and the Old Treaty: Persecutors and Persecuted in the Twenty-First Century" (2015) 16 Chicago J of Intl L 81

232 This is defined above at $\mathrm{n} 54$.

233 McAdam "Seven reasons", above n 83. 
party to the Convention and abides by it. States are increasingly, in the context of the current refugee crisis, taking measures that are not in accordance with the Convention. That this is the case must weaken the Convention and, importantly, any customary international law arising from aspects of it, such as the principle of non-refoulement.

Ideally, the Convention should be renegotiated to allow groups currently meeting the definition of refugee to be properly protected by it. There should be sanctions for states that breach it. The Convention should also be renegotiated to require true burden sharing between states. In addition, it should either be expanded to cover groups at risk of serious harm not currently covered by it or separate treaties should be entered into to cover those groups. There is, however, little chance of any of those things occurring in the current political environment.

There has been a move internationally to try to articulate principles and encourage voluntary measures to deal with the current crisis. To the extent that these rely on human rights and humanitarian principles, they can be seen as based on treaties or in some cases on customary international law. But most have moral force only, which is of little utility unless it leads to action.

There needs to be a unified, global approach to addressing the crisis and preventing one from arising in the future. It is clear that the status quo, including the uneven burden sharing of refugees and other displaced persons, both promotes human suffering and undermines international law. The process started by the New York Declaration does show some international will to take concrete steps for refugees and other displaced persons but progress is not likely to be speedy, especially because domestic attitudes towards measures that might involve more displaced persons being taken in by developed nations are likely to remain largely hostile. Cost sharing and aid may be somewhat more palatable but even these measures will only succeed in the long-term. In the meantime however, the human suffering will continue. 
